\title{
Angiogenesis and Immunity in Renal Carcinoma: Can We Turn an Unhappy Relationship into a Happy Marriage?
}

\author{
Alessia Mennitto ${ }^{1, *}$, Veronica Huber ${ }^{2}$, Raffaele Ratta ${ }^{3}$, Pierangela Sepe ${ }^{1}$, Filippo de Braud ${ }^{1,4}$, \\ Giuseppe Procopio ${ }^{1}$, Valentina Guadalupi ${ }^{1}$, Mélanie Claps ${ }^{1}$, Marco Stellato ${ }^{1}$, Elena Daveri ${ }^{2}$, \\ Licia Rivoltini $^{2}$ and Elena Verzoni ${ }^{1}$ \\ 1 Department of Medical Oncology, Fondazione IRCCS Istituto Nazionale dei Tumori, 20133 Milan, Italy; \\ pieranela.sepe@istitutotumori.mi.it (P.S.); filippo.debraud@istitutotumori.mi.it (F.d.B.); \\ giuseppe.procopio@istitutotumori.mi.it (G.P.); valentina.guadalupi@istitutotumori.mi.it (V.G.); \\ melanie.claps@istitutotumori.mi.it (M.C.); marco.stellato@istitutotumori.mi.it (M.S.); \\ elena.verzoni@istitutotumori.mi.it (E.V.) \\ 2 Unit of Immunotherapy of Human Tumors, Fondazione IRCCS Istituto Nazionale dei Tumori, 20133 Milan, \\ Italy; veronica.huber@istitutotumori.mi.it (V.H.); elena.daveri@istitutotumori.mi.it (E.D.); \\ licia.rivoltini@istitutotumori.mi.it (L.R.) \\ 3 Oncology and Supportive Care Department, Hôpital Foch, 40 Rue Worth, 92151 Suresnes, France; \\ r.ratta@hopital-foch.com \\ 4 Department of Oncology and Hemato-Oncology, University of Milan, 20122 Milan, Italy \\ * Correspondence: alessia.mennitto@istitutotumori.mi.it
}

Received: 27 February 2020; Accepted: 26 March 2020; Published: 28 March 2020

Abstract: The frontline treatment options for patients with metastatic renal cell carcinoma (mRCC) are evolving rapidly since the approval of combination immunotherapies by the U.S. Food and Drug Administration (USFDA) and the European Medicines Agency (EMA). In particular, in combination with vascular endothelial growth factor receptor (VEGFR) tyrosine-kinase inhibitors (TKIs), immune checkpoint inhibitors (ICIs) have significantly improved the outcome of patients with mRCC compared to TKI monotherapy. Here, we review the preclinical data supporting the combination of ICIs with VEGFR TKIs. The VEGF-signaling inhibition could ideally sustain immunotherapy through a positive modulation of the tumor microenvironment (TME). Antiangiogenetics, in fact, with their inhibitory activity on myelopoiesis that indirectly reduces myeloid-derived suppressor cells (MDSCs) and regulatory T cells' (Tregs) frequency and function, could have a role in determining an effective anti-tumor immune response. These findings are relevant for the challenges posed to clinicians concerning the clinical impact on treatment strategies for mRCC.

Keywords: metastatic renal cell carcinoma; angiogenesis; immunotherapy; tyrosine-kinase inhibitors; immunomodulation; immune checkpoint inhibitors

\section{Introduction}

Renal cell carcinoma (RCC) represents the seventh most common cancer, with 330,000 cases diagnosed and more than 140,000 deaths per year worldwide [1].

Over the last decades, the therapeutic scenario of metastatic RCC (mRCC) has radically changed. Until 2005, interferon alfa (IFN- $\alpha$ ) and high-dose interleukin-2 (HD IL-2) were the standard of care for the treatment of mRCC $[2,3]$. However, their impact on immune-escape mechanisms was limited, and responses to treatments were often poor, not durable and associated with a bad tolerability [4].

Recently, a better understanding of the biological and molecular basis of RCC has led to the development and approval of new targeted agents: the majority of these drugs are directed against the 
vascular endothelial growth factor (VEGF)/VEGF receptors (VEGFRs) pathway (bevacizumab, sorafenib, sunitinib, pazopanib, axitinib and cabozantinib) [5-9]; the mammalian target of the rapamycin (mTOR) pathway (everolimus and temsirolimus) [10,11] and the PD-1/PD-L1 pathway (nivolumab) [12,13].

By targeting endothelial cell proliferation, tumor angiogenesis and growth and by stimulating the immune system, these drugs have improved clinical outcomes. Indeed, response rates (RR) exceed $30 \%$, and median overall survival (mOS) is almost two years, depending on patient risk profile, the type of treatment and other clinical variables [14].

Moreover, clinical trials have shown that the combination of VEGFR tyrosine-kinase inhibitors (TKIs) and antibodies targeting PD-1 and PD-L1 present stronger activity when compared to TKI monotherapy [15].

RCC represents a paradigmatic example of a tumor with diverse host reactions taking place, allowing to study how these responses might influence tumor growth. Indeed, RCC is featured by profound neoangiogenic processes, mostly driven by oncogenic hallmarks linked to the von-Hippel Lindau (VHL) gene. On the other hand, RCC is also a quite immunogenic cancer, displaying an extraordinarily rich and heterogeneous immune infiltrate, as depicted in the excellent papers recently published on RCC immune atlas [16]. Understanding how angiogenesis and immunity do crosstalk within the tumor microenvironment (TME) and influence each other is a key point to guide therapeutic choices and sequences in a patient-tailored approach to maximize clinical efficacy.

\section{Mutually Exclusive Features of Clear Cell Renal Carcinoma Microenvironment}

Together with melanoma, RCC has been considered for decades the most immunogenic among human cancer types. Its rich microenvironment, characterized by a plethora of immune cells encompassing T cells, myeloid cells, macrophages, granulocytes, natural killer (NK) cells and other subsets [17], has for long been considered a unique feature. In particular, kidney cancer has been reported to display the highest level of T cell infiltration score among 19 different tumor types [18], indicating the active reaction of the host immune defenses to restrain tumor growth. $T$ cells usually are triggered by the expression on tumor cells of immunogenic determinants (represented by short fragments of antigenic proteins bound to HLA-class I or II molecules) stemming from the altered protein repertoire. While these alterations often originate from DNA mutations related to cancer genetic instability, in the case of RCC, the number of somatic missense mutations is quite low, followed only by thyroid cancer and lower grade glioma [18]. Instead, tumor-specific neoantigens are generated by the abundance of insertions-and-deletions detected in RCC cell DNA [19] and by the highly functional antigen-processing-machinery genes that favor antigen presentation by cancer cells [20].

This remarkably immunogenic scenario is also mirrored at the transcriptional level. Indeed, mRNA signatures identified three main clusters on the basis of the immune infiltrate: tumors featured by $\mathrm{T}$ cell-enriched vs. non-infiltrated signatures and a third cluster with an intermediate and heterogeneous milieu. T cell-enriched tumors show enhanced expression of genes involved in full-fledged adaptive immunity (IFNs, granzyme, perforin and Th1 cytokines), including the immune checkpoints CTLA4, PD-1, PDL-1, TIM3 and LAG3, as a sign of engaged immune escape. In contrast, pathways involved in angiogenic processes are specifically detected in non-immune-infiltrated lesions [18,21]. These latter are also enriched in transcriptomic signatures associated with immunosuppressive pathways involving myeloid cells and innate immunity, mesenchymal transition and fibrosis [21]. These apparently mutually exclusive pictures, where $\mathrm{T}$ cell immune infiltrate does not coexist with neoangiogenic processes, stem from the well-known evidence that angiogenesis mediates potent suppression on immunity, both directly, through the inhibitory activity of VEGF, and indirectly, via the induction of myeloid and lymphoid immunoregulatory cells. Interestingly, the link between angiogenesis and immunosuppression has its origin in the physiological process of wound healing (Figure 1). Here, angiogenesis and stroma remodeling promote the accrual of myeloid-derived suppressor cells (MDSCs) and regulatory $\mathrm{T}$ cells (Tregs) to avoid a potential onset of autoreactivation by $\mathrm{T}$ and $\mathrm{B}$ cells, which might hamper tissue repair [22,23]. 


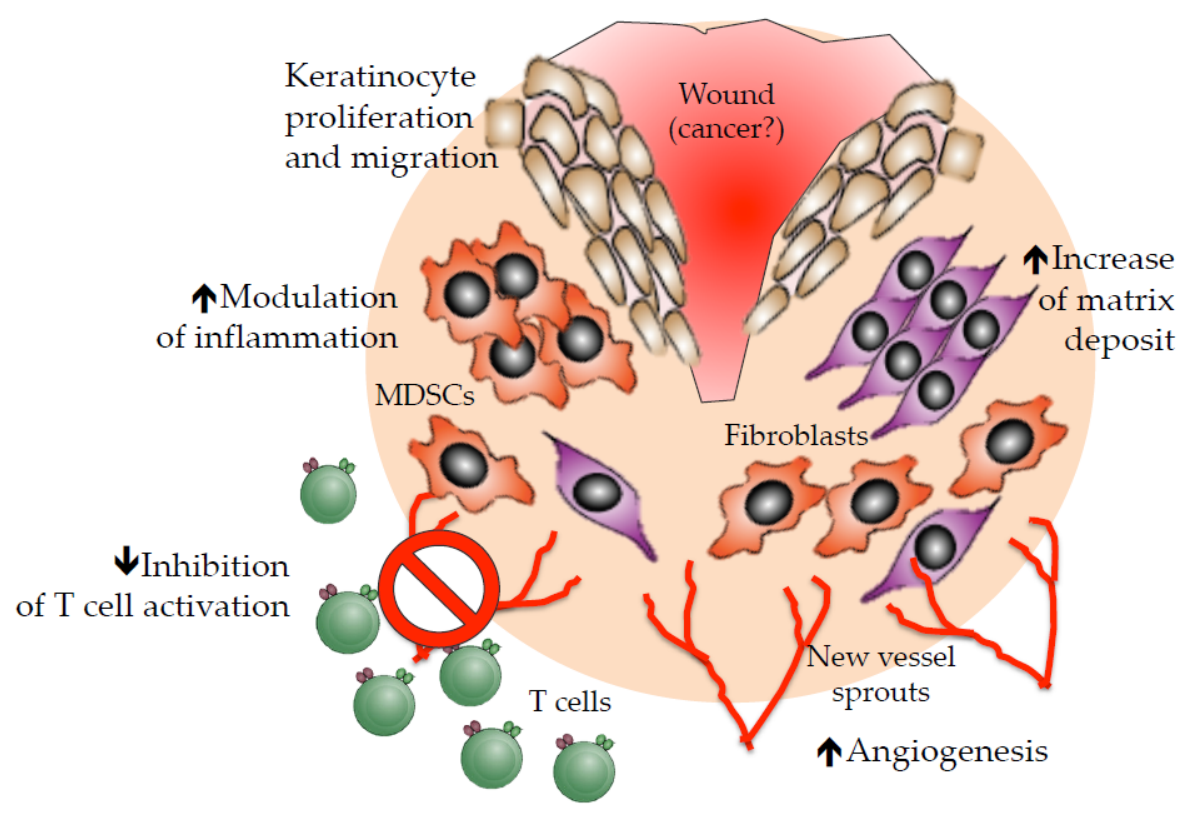

Figure 1. The link between angiogenesis and immunosuppression in the physiological process of wound healing has some homologies with cancer. MDSCs = myeloid-derived suppressor cells.

The possible implications of these interconnected processes on the therapeutic strategies to control RCC are clear and explain why this tumor responds to treatments rescuing antitumor immunity only when expressing T cell-enriched signatures, while antiangiogenic approaches are effective in $\mathrm{T}$ cell-depleted cancers [24].

\section{Crosstalk between Angiogenesis and Immunity}

Angiogenesis plays a pivotal role in the development and progression of RCC. Indeed, about $60 \%$ of RCC tumors present an inactivated VHL tumor suppressor gene through somatic mutations ( $50 \%$ of cases) or promoter methylations ( 10\%) [25]. This results in a constitutive expression of the transcription factor hypoxia-factor (HIF) $1 \alpha$ and in the overexpression of proangiogenic VEGF, platelet-derived growth factor (PDGF), erythropoietin (EPO) and insulin-like growth factor 2 (IGF2) [26]. This imbalance of pro- and antiangiogenic factors leads to multiple structural and functional abnormalities in blood vessels. In fact, these are irregularly shaped, tortuous and hyperpermeable, often covered by anergic endothelial cells, and without pericytes $[27,28]$. All these changes result in an abnormal blood flow with consequent tumor cell extravasion, intratumoral T-cell infiltration and altered antineoplastic drug delivery [29]. These mechanisms involved in tumorigenesis of RCC have been confirmed by RNA and protein microarray studies showing that the upregulation of VEGF correlated with high microvessel density and advanced stage tumor progression and poor prognosis [30,31].

In addition to their angiogenic properties, the constitutive activation of HIF1 $\alpha$ and the increased levels of VEGF induce the release of immunosuppressive factors, such as transforming growth factor $\beta$ (TGF- $\beta$ ), PD-L1 and VEGF itself. These inhibit the maturation and recruitment of dendritic cells (DCs) through the nuclear factor $\mathrm{\kappa B}(\mathrm{NF}-\mathrm{kB})$-dependent pathway [32,33], activate inflammatory cells with immunosuppressive functions, such as MDSCs [34], and increase the infiltration of tumor-associated macrophages (TAMs) [35]. DCs are antigen-presenting cells that, under physiological conditions, promote tolerance to self-antigens through the control of Tregs, specialized T cells with immunosuppressive functions [36]. However, in cancer patients, Tregs mediate tumor immune evasion through the expression of inhibitory molecules on their surface and the release of cytokines that suppress effector T cells, NK cells and other leukocytes involved in anticancer immunity [37,38]. Immune dysfunction is well-described in RCC patients who experience a shift from a type- 1 mediated CD4 ${ }^{+}$T-cell response producing IFN- $\gamma$ (involved in the effective antitumor immune response), to a type- 2 cytokine 
response implicated in the humoral immunity $[39,40]$. The accumulation of Tregs in the TME correlates with an unfavorable prognosis in several neoplasms [41,42]. MDSCs are progenitors of granulocytes and monocytes, physiologically present in the bone marrow and peripheral blood. In RCC and generally in cancer patients, tumor cells secrete multiple cytokines (e.g., CXCL-8 and CCL-2/3/4/5), which recruit MDSCs to TME and inhibit their maturation [43]. These mechanisms enhance neoangiogenesis via the VEGF pathway, immunosuppression and mesenchymal transition [44,45]. MDSCs suppress antitumor immunity through different mechanisms: they inhibit the activation of $\mathrm{CD} 4^{+}$and $\mathrm{CD} 8^{+}$lymphocytes causing the arrest of their cell cycle in the G0/G1 phase [46], reduce the proliferation and infiltration of effector T cells [47], further stimulate Tregs function [48] and drive monocytes' differentiation toward activated M2 macrophages [49]. Moreover, VEGF-driven angiogenesis downregulates vascular adhesion molecules on tumor-infiltrating endothelial cells in vivo and in vitro, reducing the infiltration of cytolytic effector leukocytes into tumors [50].

On the other hand, the immune microenvironment supports angiogenesis, too. Immune cells cooperate and synergize with stromal and cancer cells in stimulating the growth, migration and activation of endothelial cells through the production and release of a large spectrum of proangiogenic mediators, leading to blood vessel formation [51]. DCs express both VEGFR-1 and VEGFR-2 and can release pro- or antiangiogenic mediators when exposed to different combinations of cytokines. In the presence of prostaglandin E2 (PG-E2) or IL-10, DCs show an angiogenesis-promoting phenotype through the secretion of VEGF [51,52]. Eosinophils, neutrophils and TAMs have the capacity to generate new vessels through the release of a rich armamentarium of growth factors, including GM-CSF; nerve growth factor (NGF); angiogenin; TNF- $\alpha$; IL-8; VEGF; fibroblast growth factor 2 (FGF-2) [53-57]; chemokines like CXCL-3, $-4,-8,-9,-10$ and CCL2-5 and expression of the cognate receptors (CXCR-2, -4 and $-12)[58,59]$. Moreover, these cells express angiogenesis-modulating enzymes such as cycloxygenase- 2 (COX-2) and metalloproteinases (MMP-2, -7, -9 and -12) implicated in the release and mobilization of VEGF. This can destabilize the vasculature acting on matrix degradation, causing tumor migration and metastases [60]. Lastly, $\mathrm{T}$ cells are also indirectly involved in neoangiogenesis. Indeed, they bind and vehicle VEGF through the body after the acquisition of neuropilin-1 (NRP1) by trogocytosis from DCs. This transmembrane protein is expressed on neuronal and endothelial cells where it plays a crucial role in guiding axons and regulating angiogenesis [61]. Large amounts of preclinical data undoubtedly demonstrated that VEGF controls immune tolerance and surveillance in cancer. In mice genetically knocked-out for VEGF expression, a broad activation of immune-related molecules, such as chemokines mediating T-cell accrual, signaling pathways involved in T-cell activation and factors responsible for T-cell cytotoxic activity, can be detected in tumor lesions [62]. Most importantly, large parts of the therapeutic activity of antiangiogenics in murine settings rely on the rescue of antitumor immunosurveillance, as indicated by the evidence that the VEGF blockade loses its therapeutic efficacy in CD3 T-cell-depleted animals [62]. Furthermore, VEGF-A induces the upregulation of multiple immune checkpoints, such as PD-1, CTLA4, TIM3 and LAG3, in tumor-infiltrating CD8 ${ }^{+} \mathrm{T}$ cells, and VEGF-silencing potentiates tumor control mediated by the PD-1 blockade [63]. Quite recent studies demonstrate that also emerging immunotherapeutic molecules like anti-CD40 antibodies benefit from the concomitant blocking of angiogenesis, albeit a dual Ang2 and VEGF-A antagonism is required to favor intratumoral redistribution of $\mathrm{CD}^{+} \mathrm{T}$ cells [64].

Altogether, these data provide further support to the evidence that angiogenesis and immunity are processes strictly interconnected and mutually exclusive in the absence of therapeutic intervention and that interruption of angiogenesis may favor the rescue of host immune defenses mediated by immunotherapy.

\section{Effects of TKIs on Immunity}

One of the targets of TKIs is VEGFR, which, when blocked, fails to activate endothelial cells to generate new vessels in the tumor, normalizing angiogenesis and restoring an adequate tissue perfusion. The consequence is a normalization of the TME, a reduced release of growth factors and the 
recovery of host immunity [65]. Increasing evidence shows that antiangiogenic molecules overcome various immunosuppressive networks.

Sunitinib has been shown to reduce the number of systemic and intratumoral Tregs starting from the first course of therapy and, with each cycle thereafter, resulting in an improved type- 1 cytokine response. In particular, Adotevi and colleagues have observed that patients with higher levels of Tregs at baseline are more likely to present a reduction after the second or third cycle of therapy than patients presenting lower pretreatment levels of Tregs [66]. An in vitro study showed that sunitinib did not suppress the expansion of Tregs over a 14-day incubation period, suggesting that sunitinib has an indirect effect on the Treg population in vivo [67]. A possible explanation is that the activity of Tregs, which express VEGFR2 on their surface, is mediated by VEGF [68] or by MDSCs, whose percentage is reduced during sunitinib-based treatment with a synchronous higher production of IFN- $\gamma$ by T lymphocytes [69]. The depletion of MDSCs induced by sunitinib seems to be mediated by the inhibition of VEGF, c-Kit and Stat3, which, when activated, promote various immunosuppressive mechanisms (e.g., blockade of DC maturation and release of IL-10) and the expression of angiogenic and metastatic factors, inducing cancer cell resistance to the apoptotic activity of cytotoxic T cells [70,71].

The immune-modulating activities of sorafenib are less clear. In contrast to sunitinib, some detrimental effects have been described. Indeed, this drug seems to interfere with the maturation and the antigen presentation properties of DCs through the downregulation of a major histocompatibility complex and costimulatory molecules and the decreased production of immunostimulatory cytokines [72]. On the other hand, sorafenib reduces the percentage of circulating and tumor-infiltrating Tregs [73,74] and inhibits the activation of macrophages [75], shifting the immune balance to a more stimulatory setting. Similar to sunitinib, pazopanib also neutralizes the immunosuppressive effects of VEGF by reducing the expression of VEGFR1 and VEGFR2, which affect final DC maturation [76,77]. An in vitro study reported that DCs from pazopanib-treated patients expressed more activation markers HLA-DR and CCR7 and less PD-L1 as compared to DCs generated from sunitinib-treated patients [78]. Moreover, pazopanib decreases the amount of MDSCs, $\mathrm{CD} 14^{+}$monocytes and Tregs and triggers T-cell memory Th1 response, $\mathrm{CD} 8^{+}$lymphocytes and NK effectors [79]. Sunitinib and pazopanib have a similar pattern of receptor recognition but different affinities for VEGFR1. Consequently, a diversity of immune modulation effects of the two drugs has been observed. In particular, pazopanib displayed more activity in restoring the activation of DCs, whereas sunitinib is more efficient in potentiating the antitumor effector cells by eliminating immunosuppression in the TME [80]. Lastly, the immunomodulatory functions of cabozantinib occur through the reduction of MDSCs and the increased activity of circulating cytotoxic NK and CD8 ${ }^{+} \mathrm{T}$ cells, acting on both direct and antibody-mediated tumor killing [81].

In light of the immunomodulatory potential of antiangiogenics, combining anti-VEGF/VEGFR agents with ICIs has emerged as a strategy to synergize and potentiate the therapeutic efficacy of these treatments. However, it should be mentioned that, despite no side-by-side study testing the immunomodulating properties of the diverse antiangiogenics in a clinical setting having been performed, preclinical studies suggest that subtle but clinically relevant differences might exist [82-84]. One representative example is the key study of Stehle et al. [85] showing, albeit only in vitro, that some TKI-based antiangiogenics—-for instance, sorafenib and sunitinib—exert marked suppressive activity on T-cell proliferation and function, while others (e.g., axitinib) display a more neutral effect. This clearly indicates that, in combinatory approaches with immunotherapy, a more careful mechanism-driven choice of the drugs to pair in clinical trials would be indicated.

\section{Conclusions}

A major part of relevant information about human TME of the last decade undoubtedly derive from the study of RCC. Nevertheless, the application of these key principles that would help designing drug sequences and combinations is not so readily translated into the clinical setting. Quite recent trials, such as, for instance, the IMmotion151 [24], have indeed exploited tumor transcriptional signatures to 
predict responses to antiangiogenics with or without ICIs, retrospectively, but the approach is still in its infancy.

Based on the biological scenarios depicted in this review, some potential considerations could be made. Antiangiogenics with pleiotropic immunomodulating properties (like pazopanib, cabozantinib and axitinib), in combination with immunotherapeutics, could be preferred to molecules showing more immunosuppressive effects on T-cell function (e.g., sunitinib and sorafenib). Considering instead drug sequences, the administration of ICIs at the failure of antiangiogenics could be penalized by the accrual of immunosuppressive cells such as MDSCs, which associate with resistance to the VEGF blockade and an immune hostile milieu always paralleling progressing cancers $[86,87]$.

The efficacy of antiangiogenics at progression to ICIs might instead depend on the resistance mechanisms that might vary at individual patient levels $[88,89]$. If resistance is linked to the tumor loss of molecular determinants required for T-cell recognition, drugs such as pazopanib and cabozantinib that induce the activation of NK cells [79,81], so abundantly represented in RCC TME [38], could be effective.

The immunomodulating property of antiangiogenic TKIs, mostly due to their direct inhibitory activity on myelopoiesis indirectly reducing MDSC frequency and function [79,81], could also be exploited in a more innovative fashion based on their activity kinetics. Indeed, systemic immunomodulation occurs rapidly but transiently, being detectable in peripheral blood at three months but mostly disappearing at six months [79]. This effect could be exploited to conceive the use of antiangiogenics as a sort of "conditioning" treatment to favor a response to immunotherapy. Indeed, the administration of immune checkpoint blockers at TKI-induced MDSC nadir, coinciding also with an increase of PD- ${ }^{+}$-activated T and NK cells, holds promises to potentiate clinical efficacy significantly. Sequential alternate therapeutic schedules are not so common in the treatment of solid tumors, but they are often applied for patient conditioning in hemato-oncology [90-92]. The use of alternate schedules based on a defined biological rationale could help maximize efficacy while reducing the risk of resistance and possibly also of toxicity.

Thanks to the availability of therapeutic drugs with defined immunomodulating properties, RCC could represent an ideal clinical setting to investigate whether tailoring treatments based on the immune profile of individual patients and tumors might contribute to increased disease control in the context of a more innovative view of precision oncology.

Author Contributions: A.M. and L.R. wrote the manuscript, with the contributions of R.R. and P.S. V.H. made the figure. All authors have participated in reviewing and editing the manuscript and approved the draft submission. All authors have read and agreed to the published version of the manuscript.

Funding: This research was funded by the Italian Ministry of Health (RF-2016-02363001 to G.P.).

Acknowledgments: This study was supported by the Italian Ministry of Health (RF-2016-02363001 to G.P.) and Fondi 5x1000 Ministero della Salute 2015 (D/17/1VH to V.H.).

Conflicts of Interest: Dr. Ratta reports personal fees for advisory boards from Pfizer; Dr. Procopio reports personal fees from Bayer, BMS, Ipsen, Merck, MSD, Novartis and Pfizer outside of the submitted work; Prof. de Braud reports personal fees from Daiichi Sankyo, Ignyta, Novartis, Amgen, Pfizer, Octimet Oncology, Incyte, Teofarma, Pierre Fabre, Roche, EMD Serono, BMS, and Hoffman La Roche outside of the submitted work; Dr. Rivoltini is a consultant in educational and advisory programs for Bms, Merck, Pfizer, Novartis and Menarini and Dr. Verzoni reports personal fees for advisory boards from Novartis, Ipsen and Pfizer outside of the submitted work. The other authors declare no conflicts of interest.

\section{References}

1. Capitanio, U.; Montorsi, F. Renal cancer. Lancet 2016, 387, 894-906. [CrossRef]

2. Fyfe, G.; Fisher, R.I.; Rosenberg, S.A.; Sznol, M.; Parkinson, D.R.; Louie, A.C. Results of treatment of 255 patients with metastatic renal cell carcinoma who received high-dose recombinant interleukin-2 therapy. J. Clin. Oncol. 1995, 13, 688-696. [CrossRef] [PubMed]

3. Negrier, S.; Escudier, B.; Lasset, C.; Douillard, J.Y.; Savary, J.; Chevreau, C.; Ravaud, A.; Mercatello, A.; Peny, J.; Mousseau, M.; et al. Recombinant human interleukin-2, recombinant human interferon alfa-2a, or 
both in metastatic renal-cell carcinoma. Groupe Francais d'Immunotherapie. N. Engl. J. Med. 1998, 338, 1272-1278. [CrossRef] [PubMed]

4. Ratta, R.; Zappasodi, R.; Raggi, D.; Grassi, P.; Verzoni, E.; Necchi, A.; Di Nicola, M.; Salvioni, R.; de Braud, F.; Procopio, G. Immunotherapy advances in uro-genital malignancies. Crit. Rev. Oncol. Hematol. 2016, 105, 52-64. [CrossRef] [PubMed]

5. Escudier, B.; Eisen, T.; Stadler, W.M.; Szczylik, C.; Oudard, S.; Staehler, M.; Negrier, S.; Chevreau, C.; Desai, A.A.; Rolland, F.; et al. Sorafenib for treatment of renal cell carcinoma: Final efficacy and safety results of the phase III treatment approaches in renal cancer global evaluation trial. J. Clin. Oncol. 2009, 27, 3312-3318. [CrossRef]

6. Motzer, R.J.; Hutson, T.E.; Tomczak, P.; Michaelson, M.D.; Bukowski, R.M.; Rixe, O.; Oudard, S.; Negrier, S.; Szczylik, C.; Kim, S.T.; et al. Sunitinib versus interferon alfa in metastatic renal-cell carcinoma. N. Engl. J. Med. 2007, 356, 115-124. [CrossRef] [PubMed]

7. Rini, B.I.; Halabi, S.; Rosenberg, J.E.; Stadler, W.M.; Vaena, D.A.; Ou, S.S.; Archer, L.; Atkins, J.N.; Picus, J.; Czaykowski, P.; et al. Bevacizumab plus interferon alfa compared with interferon alfa monotherapy in patients with metastatic renal cell carcinoma: CALGB 90206. J. Clin. Oncol. 2008, 26, 5422-5428. [CrossRef]

8. Sternberg, C.N.; Davis, I.D.; Mardiak, J.; Szczylik, C.; Lee, E.; Wagstaff, J.; Barrios, C.H.; Salman, P.; Gladkov, O.A.; Kavina, A.; et al. Pazopanib in locally advanced or metastatic renal cell carcinoma: Results of a randomized phase III trial. J. Clin. Oncol. 2010, 28, 1061-1068.

9. Choueiri, T.K.; Escudier, B.; Powles, T.; Mainwaring, P.N.; Rini, B.I.; Donskov, F.; Hammers, H.; Hutson, T.E.; Lee, J.L.; Peltola, K.; et al. METEOR Investigators. Cabozantinib versus everolimus in advanced renal-cell carcinoma. N. Engl. J. Med. 2015, 373, 1814-1823. [CrossRef]

10. Motzer, R.J.; Escudier, B.; Oudard, S.; Hutson, T.E.; Porta, C.; Bracarda, S.; Grünwald, V.; Thompson, J.A.; Figlin, R.A.; Hollaender, N.; et al. RECORD-1 Study Group. Phase 3 trial of everolimus for metastatic renal cell carcinoma: Final results and analysis of prognostic factors. Cancer 2010, 116, 4256-4265. [CrossRef]

11. Hudes, G.; Carducci, M.; Tomczak, P.; Dutcher, J.; Figlin, R.; Kapoor, A.; Staroslawska, E.; Sosman, J.; McDermott, D.; Bodrogi, I.; et al. Global ARCC Trial. Temsirolimus, interferon alfa, or both for advanced renal-cell carcinoma. N. Engl. J. Med. 2007, 356, 2271-2281. [PubMed]

12. Motzer, R.; Escudier, B.; McDermott, D.; George, S.; Hammers, H.J.; Srinivas, S.; Tykodi, S.S.; Sosman, J.A.; Procopio, G.; Plimack, E.R.; et al. CheckMate 025 Investigators. Nivolumab versus everolimus in advanced renal-cell carcinoma. N. Engl. J. Med. 2015, 373, 1803-1813. [CrossRef] [PubMed]

13. Mennitto, A.; Grassi, P.; Ratta, R.; Grassi, P.; Ratta, R.; Verzoni, E.; Prisciandaro, M.; Procopio, G. Nivolumab in the treatment of advanced renal cell carcinoma: Clinical trial evidence and experience. Ther. Adv. Urol. 2016, 8, 319-326. [PubMed]

14. Calvo, E.; Schmidinger, M.; Heng, D.Y.; Grünwald, V.; Escudier, B. Improvement in survival end points of patients with metastatic renal cell carcinoma through sequential targeted therapy. Cancer Treat. Rev. 2016, 50, 109-117. [CrossRef] [PubMed]

15. Salgia, N.J.; Dara, Y.; Bergerot, P.; Salgia, M.; Pal, S.K. The Changing Landscape of Management of Metastatic Renal Cell Carcinoma: Current Treatment Options and Future Directions. Curr. Treat. Options Oncol. 2019, 20, 41. [CrossRef] [PubMed]

16. Chevrier, S.; Levine, J.H.; Zanotelli, V.R.T.; Silina, K.; Schulz, D.; Bacac, M.; Ries, C.H.; Ailles, L.; Jewett, M.A.S.; Moch, H.; et al. An Immune Atlas of Clear Cell Renal Cell Carcinoma. Cell 2017, 169, 736-749.

17. Drake, C.G.; Stein, M.N. The Immunobiology of Kidney Cancer. J. Clin. Oncol. 2018, 36, 3547-3552.

18. Şenbabaoğlu, Y.; Gejman, R.S.; Winer, A.G.; Liu, M.; Van Allen, E.M.; de Velasco, G.; Miao, D.; Ostrovnaya, I.; Drill, E.; Luna, A.; et al. Tumor immune microenvironment characterization in clear cell renal cell carcinoma identifies prognostic and immunotherapeutically relevant messenger RNA signatures. Genome Biol. 2016, 17, 231. [CrossRef]

19. Turajlic, S.; Litchfield, K.; Xu, H.; Rosenthal, R.; McGranahan, N.; Reading, J.L.; Wong, Y.N.S.; Rowan, A.; Kanu, N.; Al Bakir, M.; et al. Insertion-and-deletion-derived tumour-specific neoantigens and the immunogenic phenotype: A pan-cancer analysis. Lancet Oncol. 2017, 18, 1009-1021. [CrossRef]

20. Ricketts, C.J.; De Cubas, A.A.; Fan, H.; Smith, C.C.; Lang, M.; Reznik, E.; Bowlby, R.; Gibb, E.A.; Akbani, R.; Beroukhim, R.; et al. The Cancer Genome Atlas Comprehensive Molecular Characterization of Renal Cell Carcinoma. Cell Rep. 2018, 23, 313-326. [CrossRef] 
21. Van den Heuvel, C.N.A.M.; van Ewijk, A.; Zeelen, C.; de Bitter, T.; Huynen, M.; Mulders, P.; Oosterwijk, E.; Leenders, W.P.J. Molecular Profiling of Druggable Targets in Clear Cell Renal Cell Carcinoma through Targeted RNA Sequencing. Front. Oncol. 2019, 9, 117. [PubMed]

22. Groth, C.; Hu, X.; Weber, R.; Fleming, V.; Altevogt, P.; Utikal, J.; Umansky, V. Immunosuppression mediated by myeloid-derived suppressor cells (MDSCs) during tumour progression. Br. J. Cancer 2019, 120, 16-25. [CrossRef] [PubMed]

23. Rivera, L.B.; Bergers, G. Intertwined regulation of angiogenesis and immunity by myeloid cells. Trends Immunol. 2015, 36, 240-249. [PubMed]

24. Atkins, M.B.; McDermott, D.F.; Powles, T.; Escudier, B.; McDermott, D.F.; Suarez, C.; Bracarda, S.; Stadler, W.M.; Donskov, F.; Lee, J.L.; et al. Atezolizumab plus bevacizumab versus sunitinib in patients with previously untreated metastatic renal cell carcinoma (IMmotion151): A multicentre, open-label, phase 3, randomised controlled trial. Lancet 2019, 393, 2404-2415.

25. Rini, B.I.; Small, E.J. Biology and clinical development of vascular endothelial growth factor-targeted therapy in renal cell carcinoma. J. Clin. Oncol. 2005, 23, 1028-1043. [CrossRef]

26. Na, X.; Wu, G.; Ryan, C.K.; di'Santagnese, P.A.; Messing, E.M. Overproduction of vascular endothelial growth factor related to von Hippel-Lindau tumor suppressor gene mutations and hypoxia-inducible factor-1 alpha expression in renal cell carcinomas. J. Urol. 2003, 170 (2 Pt 1), 588-592. [CrossRef]

27. Goel, S.; Duda, D.G.; Xu, L.; Munn, L.L.; Boucher, Y.; Fukumura, D.; Jain, R.K. Normalization of the vasculature for treatment of cancer and other diseases. Physiol. Rev. 2011, 91, 1071-1121. [CrossRef]

28. Melero, I.; Rouzaut, A.; Motz, G.T.; Coukos, G. T-cell and NK-cell infiltration into solid tumors: A key limiting factor for efficacious cancer immunotherapy. Cancer Discov. 2014, 4, 522-526.

29. Azzi, S.; Hebda, J.K.; Gavard, J. Vascular permeability and drug delivery in cancers. Front. Oncol. 2013, 3, 211. [CrossRef]

30. Jacobsen, J.; Grankvist, K.; Rasmuson, T.; Bergh, A.; Landberg, G.; Ljungberg, B. Expression of vascular endothelial growth factor protein in human renal cell carcinoma. BJU Int. 2004, 93, 297-302. [CrossRef]

31. Paradis, V.; Lagha, N.B.; Zeimoura, L.; Blanchet, P.; Eschwege, P.; Ba, N.; Benoît, G.; Jardin, A.; Bedossa, P. Expression of vascular endothelial growth factor in renal cell carcinomas. Virchows Arch. 2000, 436, 351-356. [CrossRef] [PubMed]

32. Wada, J.; Suzuki, H.; Fuchino, R.; Yamasaki, A.; Nagai, S.; Yanai, K.; Koga, K.; Nakamura, M.; Tanaka, M.; Morisaki, T.; et al. The contribution of vascular endothelial growth factor to the induction of regulatory T-cells in malignant effusions. Anticancer Res. 2009, 29, 881-883.

33. Oyama, T.; Ran, S.; Ishida, T.; Nadaf, S.; Kerr, L.; Carbone, D.P.; Gabrilovich, D.I. Vascular Endothelial Growth Factor Affects Dendritic Cell Maturation through the Inhibition of Nuclear Factor-kB Activation in Hemopoietic progenitor cells. J. Immunol. 1998, 160, 1224-1232.

34. Noman, M.Z.; Desantis, G.; Janji, B.; Hasmim, M.; Karray, S.; Dessen, P.; Bronte, V.; Chouaib, S. PD-L1 is a novel direct target of HIF-1 $\alpha$, and its blockade under hypoxia enhanced MDSC-mediated T cell activation. J. Exp. Med. 2014, 211, 781-790. [CrossRef] [PubMed]

35. Varney, M.L.; Johansson, S.L.; Singh, R.K. Tumour-associated macrophage infiltration, neovascularization and aggressiveness in malignant melanoma: Role of monocyte chemotactic protein-1 and vascular endothelial growth factor-A. Melanoma Res. 2005, 15, 417-425. [CrossRef] [PubMed]

36. Belkaid, Y.; Oldenhove, G. Tuning microenvironments: Induction of regulatory T cells by dendritic cells. Immunity 2008, 29, 362-371. [CrossRef] [PubMed]

37. Curiel, T.J. Tregs and rethinking cancer immunotherapy. J. Clin. Investig. 2007, 117, 1167-1174. [CrossRef] [PubMed]

38. Finke, J.H.; Rayman, P.A.; Ko, J.S.; Bradley, J.M.; Gendler, S.J.; Cohen, P.A. Modification of the tumor microenvironment as a novel target of renal cell carcinoma therapeutics. Cancer J. 2013, 19, 353-364. [CrossRef]

39. Toes, R.E.; Ossendorp, F.; Offringa, R.; Melief, C.J. CD4 T cells and their role in antitumor immune responses. J. Exp. Med. 1999, 189, 753-756. [CrossRef]

40. Nishimura, T.; Iwakabe, K.; Sekimoto, M.; Ohmi, Y.; Yahata, T.; Nakui, M.; Sato, T.; Habu, S.; Tashiro, H.; Sato, M.; et al. Distinct role of antigen-specific T helper type 1 (Th1) and Th2 cells in tumor eradication in vivo. J. Exp. Med. 1999, 190, 617-627. [CrossRef] 
41. Whiteside, T.L. Immune responses to malignancies. J. Allergy Clin. Immunol. 2010, 125 (Suppl. S2), S272-S283. [CrossRef] [PubMed]

42. Griffiths, R.W.; Elkord, E.; Gilham, D.E.; Ramani, V.; Clarke, N.; Stern, P.L.; Hawkins, R.E. Frequency of regulatory $\mathrm{T}$ cells in renal cell carcinoma patients and investigation of correlation with survival. Cancer Immunol. Immunother. 2007, 56, 1743-1753. [CrossRef] [PubMed]

43. Gabrilovich, D.I.; Nagaraj, S. Myeloid-derived suppressor cells as regulators of the immune system. Nat. Rev. Immunol. 2009, 9, 162-174. [CrossRef] [PubMed]

44. Parihar, J.S.; Tunuguntla, H.S. Role of chemokines in renal cell carcinoma. Rev. Urol. 2014, 16, 118-121. [PubMed]

45. Kumar, V.; Patel, S.; Tcyganov, E.; Gabrilovich, D.I. The Nature of Myeloid-Derived Suppressor Cells in the Tumor Microenvironment. Trends Immunol. 2016, 37, 208-220. [CrossRef] [PubMed]

46. Sevko, A.; Umansky, V. Myeloid-Derived Suppressor Cells Interact with Tumors in Terms of Myelopoiesis, Tumorigenesis and Immunosuppression: Thick as Thieves. J. Cancer 2013, 4, 3-11. [CrossRef]

47. Fujimura, T.; Mahnke, K.; Enk, A.H. Myeloid derived suppressor cells and their role in tolerance induction in cancer. J. Dermatol. Sci. 2010, 59, 1-6. [CrossRef]

48. Serafini, P.; Mgebroff, S.; Noonan, K.; Borrello, I. Myeloid-derived suppressor cells promote cross-tolerance in B-cell lymphoma by expanding regulatory T cells. Cancer Res. 2008, 68, 5439-5449. [CrossRef]

49. Tiemessen, M.M.; Jagger, A.L.; Evans, H.G.; van Herwijnen, M.J.; John, S.; Taams, L.S. CD4+CD25+Foxp3+ regulatory $\mathrm{T}$ cells induce alternative activation of human monocytes/macrophages. Proc. Natl. Acad. Sci. USA 2007, 104, 19446-19451. [CrossRef]

50. Griffioen, A.W.; Damen, C.A.; Martinotti, S.; Blijham, G.H.; Groenewegen, G. Endothelial intercellular adhesion molecule- 1 expression is suppressed in human malignancies: The role of angiogenic factors. Cancer Res. 1996, 56, 1111-1117.

51. Ribatti, D.; Crivellato, E. Immune cells and angiogenesis. J. Cell. Mol. Med. 2009, 13, 2822-2833. [CrossRef] [PubMed]

52. Riboldi, E.; Musso, T.; Moroni, E.; Urbinati, C.; Bernasconi, S.; Rusnati, M.; Adorini, L.; Presta, M.; Sozzani, S. Cutting edge: Proangiogenic properties of alternatively activated dendritic cells. J. Immunol. 2005, 175, 2788-2792. [CrossRef] [PubMed]

53. Kita, H.; Ohnishi, T.; Okubo, Y.; Weiler, D.; Abrams, J.S.; Gleich, G.J. Granulocyte/macrophage colony-stimulating factor and interleukin 3 release from human peripheral blood eosinophils and neutrophils. J. Exp. Med. 1991, 174, 745-748. [CrossRef] [PubMed]

54. Solomon, A.; Aloe, L.; Pe'er, J.; Frucht-Pery, J.; Bonini, S.; Bonini, S.; Levi-Schaffer, F. Nerve growth factor is preformed in and activates human peripheral blood eosinophils. J. Allergy Clin. Immunol. 1998, 102, 454-460. [CrossRef]

55. Hoshino, M.; Takahashi, M.; Aoike, N. Expression of vascular endothelial growth factor, basic fibroblast growth factor, and angiogenin immunoreactivity in asthmatic airways and its relationship to angiogenesis. J. Allergy Clin. Immunol. 2001, 107, 295-301. [CrossRef]

56. Sunderkötter, C.; Goebeler, M.; Schulze-Osthoff, K.; Bhardwaj, R.; Sorg, C. Macrophage-derived angiogenesis factors. Pharmacol. Ther. 1991, 51, 195-216. [CrossRef]

57. Klimp, A.H.; Hollema, H.; Kempinga, C.; van der Zee, A.G.; de Vries, E.G.; Daemen, T. Expression of cyclooxygenase-2 and inducible nitric oxide synthase in human ovarian tumors and tumor-associated macrophages. Cancer Res. 2001, 61, 7305-7309.

58. Chavakis, T.; Cines, D.B.; Rhee, J.S.; Liang, O.D.; Schubert, U.; Hammes, H.P.; Higazi, A.A.; Nawroth, P.P.; Preissner, K.T.; Bdeir, K. Regulation of neovascularization by human neutrophil peptides (alpha-defensins): A link between inflammation and angiogenesis. FASEB J. 2004, 18, 1306-1308. [CrossRef]

59. Owen, J.L.; Mohamadzadeh, M. Macrophages and chemokines as mediators of angiogenesis. Front. Physiol. 2013, 4, 159. [CrossRef]

60. Murdoch, C.; Muthana, M.; Coffelt, S.B.; Lewis, C.E. The role of myeloid cells in the promotion of tumour angiogenesis. Nat. Rev. Cancer 2008, 8, 618-631. [CrossRef]

61. Bourbié-Vaudaine, S.; Blanchard, N.; Hivroz, C.; Roméo, P.H. Dendritic cells can turn CD4+ T lymphocytes into vascular endothelial growth factor-carrying cells by intercellular neuropilin-1 transfer. J. Immunol. 2006, 177, 1460-1469. [CrossRef] [PubMed] 
62. Courau, T.; Nehar-Belaid, D.; Florez, L.; Levacher, B.; Vazquez, T.; Brimaud, F.; Bellier, B.; Klatzmann, D. TGF- $\beta$ and VEGF cooperatively control the immunotolerant tumor environment and the efficacy of cancer immunotherapies. JCI Insight 2016, 1, e85974. [CrossRef] [PubMed]

63. Voron, T.; Colussi, O.; Marcheteau, E.; Pernot, S.; Nizard, M.; Pointet, A.L.; Latreche, S.; Bergaya, S.; Benhamouda, N.; Tanchot, C.; et al. VEGF-A modulates expression of inhibitory checkpoints on CD8+ T cells in tumors. J. Exp. Med. 2015, 212, 139-148. [CrossRef] [PubMed]

64. Kashyap, A.S.; Schmittnaegel, M.; Rigamonti, N.; Pais-Ferreira, D.; Mueller, P.; Buchi, M.; Ooi, C.H.; Kreuzaler, M.; Hirschmann, P.; Guichard, A.; et al. Optimized antiangiogenic reprogramming of the tumor microenvironment potentiates CD40 immunotherapy. Proc. Natl. Acad. Sci. USA 2020, 117, 541-551. [CrossRef] [PubMed]

65. Kwilas, A.R.; Donahue, R.N.; Tsang, K.Y.; Hodge, J.W. Immune consequences of tyrosine kinase inhibitors that synergize with cancer immunotherapy. Cancer Cell Microenviron. 2015, 2, e677. [PubMed]

66. Adotevi, O.; Pere, H.; Ravel, P.; Haicheur, N.; Badoual, C.; Merillon, N.; Medioni, J.; Peyrard, S.; Roncelin, S.; Verkarre, V.; et al. A decrease of regulatory T cells correlates with overall survival after sunitinib-based antiangiogenic therapy in metastatic renal cancer patients. J. Immunother. 2010, 33, 991-998. [CrossRef]

67. Finke, J.H.; Rini, B.; Ireland, J.; Rayman, P.; Richmond, A.; Golshayan, A.; Wood, L.; Elson, P.; Garcia, J.; Dreicer, R.; et al. Sunitinib reverses type-1 immune suppression and decreases T-regulatory cells in renal cell carcinoma patients. Clin. Cancer Res. 2008, 14, 6674-6682. [CrossRef]

68. Suzuki, H.; Onishi, H.; Wada, J.; Yamasaki, A.; Tanaka, H.; Nakano, K.; Morisaki, T.; Katano, M. VEGFR2 is selectively expressed by FOXP3high CD4+ Treg. Eur. J. Immunol. 2010, 40, 197-203. [CrossRef]

69. Ko, J.S.; Zea, A.H.; Rini, B.I.; Ireland, J.L.; Elson, P.; Cohen, P.; Golshayan, A.; Rayman, P.A.; Wood, L.; Garcia, J.; et al. Sunitinib mediates reversal of myeloid-derived suppressor cell accumulation in renal cell carcinoma patients. Clin. Cancer Res. 2009, 15, 2148-2157. [CrossRef]

70. Xie, T.X.; Wei, D.; Liu, M.; Gao, A.C.; Ali-Osman, F.; Sawaya, R.; Huang, S. Stat3 activation regulates the expression of matrix metalloproteinase-2 and tumor invasion and metastasis. Oncogene 2004, 23, 3550-3560. [CrossRef]

71. Noman, M.Z.; Buart, S.; Van Pelt, J.; Richon, C.; Hasmim, M.; Leleu, N.; Suchorska, W.M.; Jalil, A.; Lecluse, Y.; El Hage, F.; et al. The cooperative induction of hypoxia-inducible factor-1 alpha and STAT3 during hypoxia induced an impairment of tumor susceptibility to CTL-mediated cell lysis. J. Immunol. 2009, 182, 3510-3521. [CrossRef] [PubMed]

72. Hipp, M.M.; Hilf, N.; Walter, S.; Werth, D.; Brauer, K.M.; Radsak, M.P.; Weinschenk, T.; Singh-Jasuja, H.; Brossart, P. Sorafenib, but not sunitinib, affects function of dendritic cells and induction of primary immune responses. Blood 2008, 111, 5610-5620. [CrossRef]

73. Busse, A.; Asemissen, A.M.; Nonnenmacher, A.; Braun, F.; Ochsenreither, S.; Stather, D.; Fusi, A.; Schmittel, A.; Miller, K.; Thiel, E.; et al. Immunomodulatory effects of sorafenib on peripheral immune effector cells in metastatic renal cell carcinoma. Eur. J. Cancer 2011, 47, 690-696. [CrossRef] [PubMed]

74. Desar, I.M.; Jacobs, J.H.; Hulsbergen-vandeKaa, C.A.; Oyen, W.J.; Mulders, P.F.; van der Graaf, W.T.; Adema, G.J.; van Herpen, C.M.; de Vries, I.J. Sorafenib reduces the percentage of tumour infiltrating regulatory T cells in renal cell carcinoma patients. Int. J. Cancer 2011, 129, 507-512. [CrossRef] [PubMed]

75. Lin, J.C.; Liu, C.L.; Lee, J.J.; Liu, T.P.; Ko, W.C.; Huang, Y.C.; Wu, C.H.; Chen, Y.J. Sorafenib induces autophagy and suppresses activation of human macrophage. Int. Immunopharmacol. 2013, 15, 333-339. [CrossRef] [PubMed]

76. Dikov, M.M.; Ohm, J.E.; Ray, N.; Tchekneva, E.E.; Burlison, J.; Moghanaki, D.; Nadaf, S.; Carbone, D.P. Differential roles of vascular endothelial growth factor receptors 1 and 2 in dendritic cell differentiation. J. Immunol. 2005, 174, 215-222. [CrossRef] [PubMed]

77. Porta, C. Aspetti clinici di pazopanib: Nuovo farmaco inibitore dell'angiogenesi per il trattamento del carcinoma a cellule renali avanzato. IJPH 2011, 9 (Suppl. S2), 3.

78. Zizzari, I.G.; Napoletano, C.; Botticelli, A.; Caponnetto, S.; Calabrò, F.; Gelibter, A.; Rughetti, A.; Ruscito, I.; Rahimi, H.; Rossi, E.; et al. TK Inhibitor Pazopanib Primes DCs by Downregulation of the $\beta$-Catenin Pathway. Cancer Immunol. Res. 2018, 6, 711-722. [CrossRef]

79. Verzoni, E.; De Cecco, L.; Dugo, M.; Rinchai, D.; Bedognetti, D.; Grassi, P.; Ratta, R.; Cova, A.; Squarcina, P.; Huber, V; et al. Broad immunomodulating effect of first-line Pazopanib in metastatic renal cell carcinoma patients. Ann. Oncol. 2017, 28 (Suppl. S5), v295-v329. [CrossRef] 
80. Kumar, R.; Crouthamel, M.C.; Rominger, D.H.; Gontarek, R.R.; Tummino, P.J.; Levin, R.A.; King, A.G. Myelosuppression and kinase selectivity of multikinase angiogenesis inhibitors. Br. J. Cancer 2009, 101, 1717-1723. [CrossRef]

81. Verzoni, E.; Ferro, S.; Procopio, G.; Cova, A.; Ratta, R.; Raimondi, A.; Sepe, P.; Squarcina, P.; Lalli, L.V.; Huber, V.; et al. Potent Natural Killer (NK) and myeloid blood cell remodeling by Cabozantinib (Cabo) in pretreated metastatic renal cell carcinoma (mRCC) patients. Ann. Oncol. 2018, 29 (Suppl. S8), viii303-viii331. [CrossRef]

82. Amemiya, T.; Honma, M.; Kariya, Y.; Ghosh, S.; Kitano, H.; Kurachi, Y.; Fujita, K.I.; Sasaki, Y.; Homma, Y.; Abernethy, D.R.; et al. Elucidation of the molecular mechanisms underlying adverse reactions associated with a kinase inhibitor using systems toxicology. NPJ Syst. Biol. Appl. 2015, 1, 15005. [CrossRef] [PubMed]

83. Bracarda, S.; Porta, C.; Sabbatini, R.; Rivoltini, L. Angiogenic and immunological pathways in metastatic renal cell carcinoma: A counteracting paradigm or two faces of the same medal? The GIANUS Review. Crit. Rev. Oncol. Hematol. 2019, 139, 149-157. [CrossRef] [PubMed]

84. Flörcken, A.; Takvorian, A.; Van Lessen, A.; Singh, A.; Hopfenmüller, W.; Dörken, B.; Pezzutto, A.; Westermann, J. Sorafenib, but not sunitinib, induces regulatory T cells in the peripheral blood of patients with metastatic renal cell carcinoma. Anticancer Drugs 2012, 23, 298-302. [CrossRef]

85. Stehle, F.; Schulz, K.; Fahldieck, C.; Kalich, J.; Lichtenfels, R.; Riemann, D.; Seliger, B. Reduced immunosuppressive properties of axitinib in comparison with other tyrosine kinase inhibitors. J. Biol. Chem. 2013, 288, 16334-16347. [CrossRef]

86. Jung, K.; Heishi, T.; Khan, O.F.; Kowalski, P.S.; Incio, J.; Rahbari, N.N.; Chung, E.; Clark, J.W.; Willett, C.G.; Luster, A.D. Ly6Clo monocytes drive immunosuppression and confer resistance to anti-VEGFR2 cancer therapy. J. Clin. Investig. 2017, 127, 3039-3051. [CrossRef]

87. Komiya, T.; Huang, C.H.; Neupane, P.; Williamson, S.K.; Chalise, P. Impact of previous anti-angiogenesis treatment in nivolumab-treated advanced non-small cell lung cancer. J. Cancer Metastasis Treat. 2018, 4, 1. [CrossRef]

88. Nowicki, T.S.; Hu-Lieskovan, S.; Ribas, A. Mechanisms of Resistance to PD-1 and PD-L1 Blockade. Cancer J. 2018, 24, 47-53. [CrossRef]

89. Fares, C.M.; Van Allen, E.M.; Drake, C.G.; Allison, J.P.; Hu-Lieskovan, S. Mechanisms of Resistance to Immune Checkpoint Blockade: Why Does Checkpoint Inhibitor Immunotherapy Not Work for All Patients? Am. Soc. Clin. Oncol. Educ. Book 2019, 39, 147-164. [CrossRef]

90. Duléry, R.; Ménard, A.L.; Chantepie, S.; El-Cheikh, J.; François, S.; Delage, J.; Giannotti, F.; Ruggeri, A.; Brissot, E.; Battipaglia, G.; et al. Sequential Conditioning with Thiotepa in T Cell- Replete Hematopoietic Stem Cell Transplantation for the Treatment of Refractory Hematologic Malignancies: Comparison with Matched. Related, Haplo-Mismatched, and Unrelated Donors. Biol. Blood Marrow Transplant. 2018, 24, 1013-1021. [CrossRef]

91. Fraccaroli, A.; Prevalsek, D.; Fritsch, S.; Haebe, S.; Bücklein, V.; Schulz, C.; Hubmann, M.; Stemmler, H.J.; Ledderose, G.; Hausmann, A.; et al. Sequential HLA-haploidentical transplantation utilizing post-transplantation cyclophosphamide for GvHD prophylaxis in high-risk and relapsed/refractory AML/MDS. Am. J. Hematol. 2018, 93, 1524-1531. [CrossRef] [PubMed]

92. Zoellner, A.K.; Fritsch, S.; Prevalsek, D.; Engel, N.; Hubmann, M.; Reibke, R.; Rieger, C.T.; Hellmuth, J.C.; Haas, M.; Mumm, F.; et al. Sequential therapy combining clofarabine and T-cell-replete HLA-haploidentical. haematopoietic SCT is feasible and shows efficacy in the treatment of refractory or relapsed aggressive lymphoma. Bone Marrow Transplant. 2015, 50, 679-684. [CrossRef] [PubMed]

(C) 2020 by the authors. Licensee MDPI, Basel, Switzerland. This article is an open access article distributed under the terms and conditions of the Creative Commons Attribution (CC BY) license (http://creativecommons.org/licenses/by/4.0/). 